\title{
Approach and conservative surgical treatment of jaw ameloblastoma: case report
}

\section{Abordagem e tratamento cirúrgico conservador do ameloblastoma da mandíbula: relato de caso}

\section{Abordaje y tratamiento quirúrgico conservador del ameloblastoma de mandibula: reporte de caso}

Weslay Rodrigues da Silva ${ }^{1 凶} \underline{\mathrm{ORCID}}$, Cleiton Rone dos Santos Lima ${ }^{2 凶} \underline{\mathrm{ORCID}}$, Jailton Gomes Amancio da Silva $2 \llbracket \underline{\text { ORCID }}$, Ana Caroline Mara de Brito Martins $2 \square \underline{\text { ORCID }}$, Thayanara Silva Melo ${ }^{3 凶} \underline{\text { ORCID }}$,

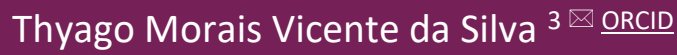

\footnotetext{
${ }^{1}$ DDS, MSc student, Postgraduate Program in Oral Pathology, Department of Dentistry, Federal University of Rio Grande do Norte, Natal, RN, Brazil.

${ }^{2}$ DDS student, School of Dentistry, University of Pernambuco, Recife, PE, Brazil.

${ }^{3}$ DDS, MSc, PhD student, Postgraduate Program in dentistry, Department of Dentistry, Federal University of Pernambuco, Recife, PE, Brazil.
}

Fecha correspondencia: Recibido: mayo de 2020

Aprobado: septiembre de 2021.

Forma de citar:

Rodrigues- da-Silva W, Rone-dosSantos-Lima C, Gomes-Amancioda-Silva J, Mara de-Brito-Martins AC, Silva-Melo T, Morais Vicenteda-Silva T. Approach and conservative surgical treatment of jaw ameloblastoma: case report. Rev. CES Odont 2021; 34(2): 188-199.

https://doi.org/10.21615/ cesodon.5658

\section{Open access}

(C) Derecho de autor

Licencia creative commons

Ética de publicaciones

Revisión por pares

\section{Abstract}

Ameloblastoma is a benign neoplasm, originated from the odontogenic epithelium. It preferentially affects the mandible and due to its infiltrative growth pattern, it has a tendency to local recurrence. Treatment varies based on clinical, histological and radiographic characteristics. The aggressive treatment, such as marginal resection, has shown good results, however, it also has greater morbidity. Conservative treatments, such as decompression, enucleation and curettage, can also be used, with specific indications, and when carefully performed, it has a good prognosis. Thus, the objective of this work is to describe a case of mandibular ameloblastoma, treated in a more conservative way. Male patient, 53 years old, presented an increase in volume in the anterior region of the mandible. The clinical and radiographic characteristics suggested that it was a cystic lesion, so decompression and incisional biopsy were performed, the diagnosis of which was cystic ameloblastoma. The decompression 
Gestión por Open Journal

System

DOI: $10.21615 /$ cesodon.5658

ISSNe 2215-9185

ISSN 0120-971X

Publica con nosotros device was maintained until bone neoformation was no longer observed, with conservative marginal resection being performed, followed by peripheral ostectomy.

Keywords: ameloblastoma; conservative treatment; decompression.

\section{Resumo}

O ameloblastoma é uma neoplasia benigna, originada no epitélio odontogênico. Afeta preferencialmente a mandíbula e, devido ao seu padrão de crescimento infiltrativo, tem tendência à recorrência local. O tratamento varia com base nas características clínicas, histológicas e radiográficas. $O$ tratamento agressivo, como a ressecção marginal, tem mostrado bons resultados, porém também apresenta maior morbidade. Tratamentos conservadores, como descompressão, enucleação e curetagem, também podem ser utilizados, com indicações específicas e, quando realizados com cuidado, apresentam bom prognóstico. Assim, o objetivo deste trabalho é descrever um caso de ameloblastoma mandibular, tratado de maneira mais conservadora. Paciente do sexo masculino, 53 anos, apresentou aumento de volume na região anterior da mandíbula. As características clínicas e radiográficas sugeriram que se tratava de uma lesão cística, pelo que foram realizadas descompressão e biópsia incisional, cujo diagnóstico era ameloblastoma cístico. $\mathrm{O}$ dispositivo de descompressão foi mantido até que a neoformação óssea não fosse mais observada, com ressecção marginal conservadora sendo realizada, seguida de ostectomia periférica.

Palavras-chave: ameloblastoma; tratamento conservador; descompressão.

\section{Resumen}

El ameloblastoma es una neoplasia benigna, originada del epitelio odontogénico. Afecta preferentemente a la mandíbula $y$, debido a su patrón de crecimiento infiltrativo, tiene tendencia a la recurrencia local. El tratamiento varía según las características clínicas, histológicas y radiográficas. El tratamiento agresivo, como la resección marginal, ha mostrado buenos resultados, sin embargo, también tiene una mayor morbilidad. Los tratamientos conservadores, como la descompresión, la enucleación y el legrado, también se pueden utilizar, con indicaciones específicas, y cuando se realiza con cuidado, tiene un buen pronóstico. Por lo tanto, el objetivo de este trabajo es describir un caso de ameloblastoma mandibular, tratado 
de una manera más conservadora. Paciente masculino, de 53 años, presentó un aumento de volumen en la región anterior de la mandíbula. Las características clínicas y radiográficas sugirieron que se trataba de una lesión quística, por lo que se realizó descompresión y biopsia incisional, cuyo diagnóstico fue ameloblastoma quístico. El dispositivo de descompresión se mantuvo hasta que ya no se observó neoformación ósea, realizándose una resección marginal conservadora, seguida de ostectomía periférica.

Palabras clave: ameloblastoma; tratamiento conservador; descompresión.

\section{Introduction}

Ameloblastoma is a benign slow-growing odontogenic neoplasm, that forms from the neoplastic odontogenic epithelium within a mature fibrous stroma devoid of ectomesenchyma. Characterized by expansion and tendency to local recurrence if it is not properly treated ${ }^{(1,2)}$; it presents as a radiolucent unilocular or multilocular lesion, which can lead to the expansion and thinning of the bone cortex ${ }^{(3)}$. Clinically it can be classified into 3 types, solid or multicystic, unicystic and peripheral. The solid type generally presents greater local aggressiveness, which differs from the unicist variant ${ }^{(4,5)}$.

About $80 \%$ of all ameloblastomas are located in the mandible, mainly in the molar region ${ }^{(6,7)}$. Due to socioeconomic situations and limited access to health services, some patients with ameloblastoma in developing countries often experience massive growth injuries before seeking care ${ }^{(8,9)}$.

The typical treatment for ameloblastoma is radical resection with safety margins. Conservative treatment can also be used and has limited indication, which may include methods such as decompression, enucleation, curettage, peripheral ostectomy and chemical or physical cauterization ${ }^{(10-13)}$. Given the above, the objective of this work was to describe a case of unicystic ameloblastoma in the mandible, treated in a more conservative way.

\section{Case Report}

A 53-year-old male patient was referred to a buccomaxillofacial surgery and traumatology service for consultation in November 2018. In the anamnesis, the patient reported a three-year increase in volume as the main complaint. On extra oral physical examination, he presented facial asymmetry (Figure 1a). In the intraoral physical examination, there was an increase in volume in the anterior region of the mandible, of hard consistency and coloration similar to mucous (Figure 1b). 


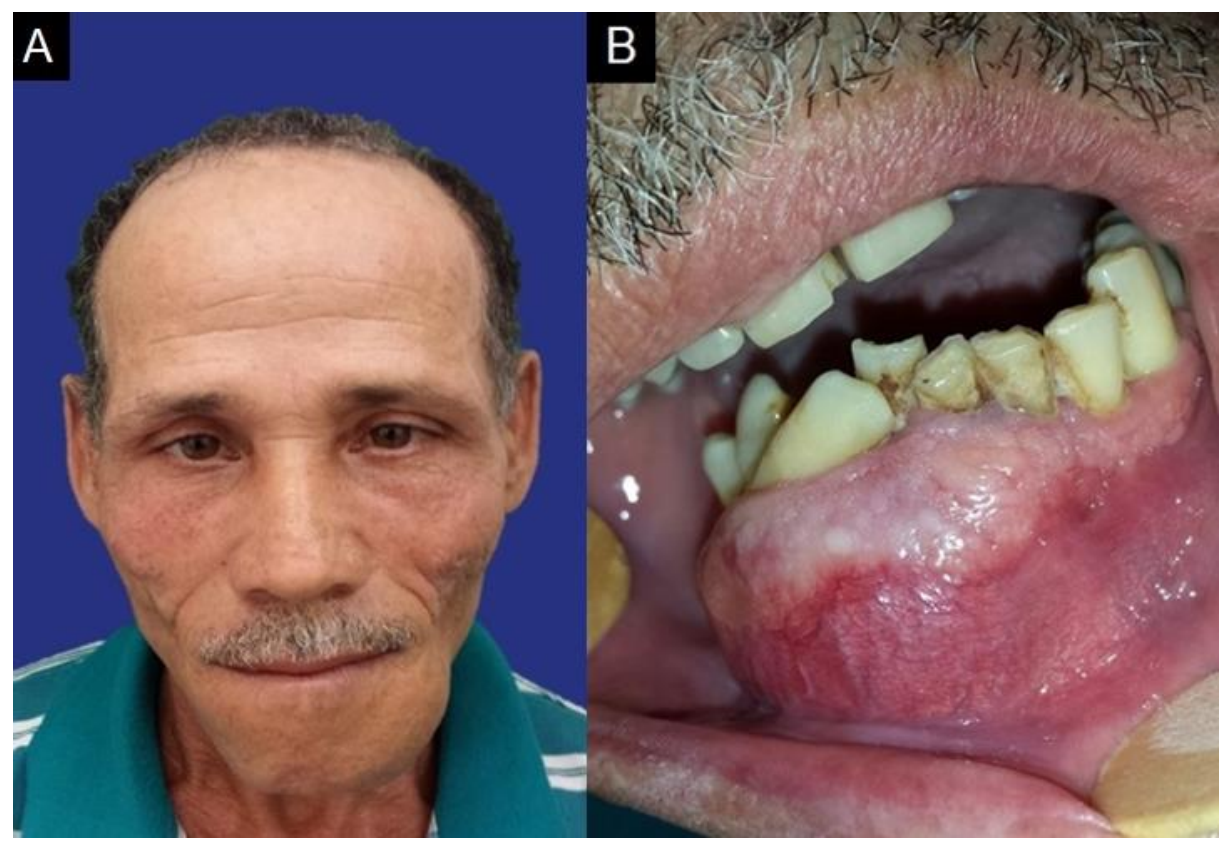

Figure 1. Initial clinical aspect. A - Front view of the patient, showing facial asymmetry. B - Intraoral view of the patient, showing an increase in the volume of normal mucosa color in the mandible.

Panoramic radiography was performed, which showed multilocular radiolucent lesion (Figure 2). The aspiration puncture revealed a brownish liquid content, suggesting that it was a cystic lesion.

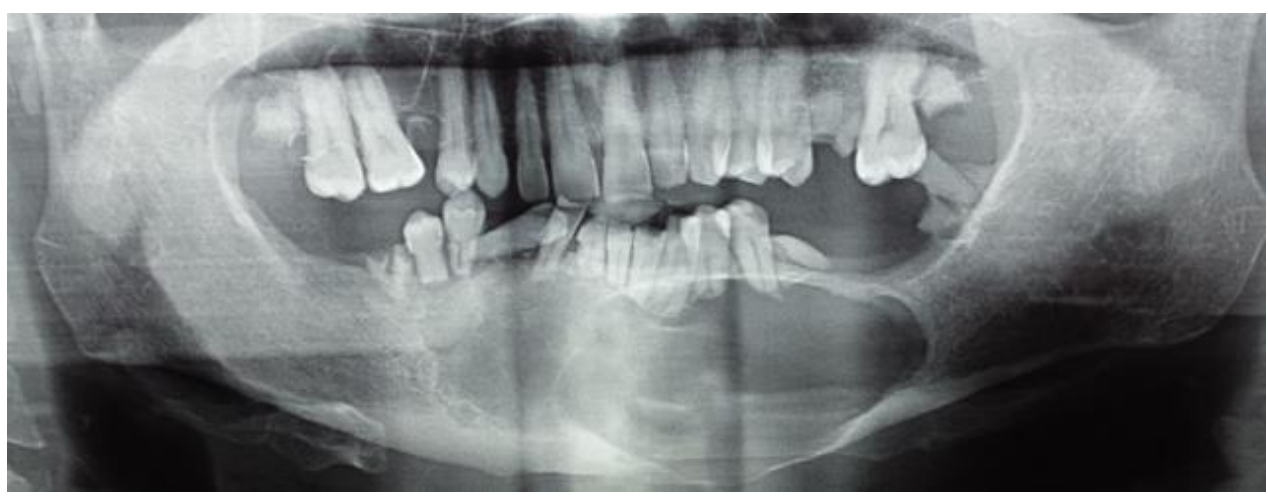

Figure 2. Panoramic radiograph showing radiolucent, well-defined, multilocular lesion, extending from the body of the mandible on the left side to the region of the tooth 45 . The lesion caused root resorption, tooth displacement, bulging and thinning of the base of the mandible on the left side. 
Therefore, under local anesthesia, a decompression device was placed and an incisional biopsy was performed, the diagnosis of which was suggestive of unicit ameloblastoma.

Due to the size of the lesion, it was decided to maintain the decompression device, requiring quarterly follow-up, to evaluate the bone neoformation (Figure 3 ), and the extraction of the lower teeth. After one year, it was noted that there was no bone neoformation, so conservative marginal resection was performed maintaining the basilar of the mandible, next to the affected mucous, and peripheral ostectomy (Figure 4).

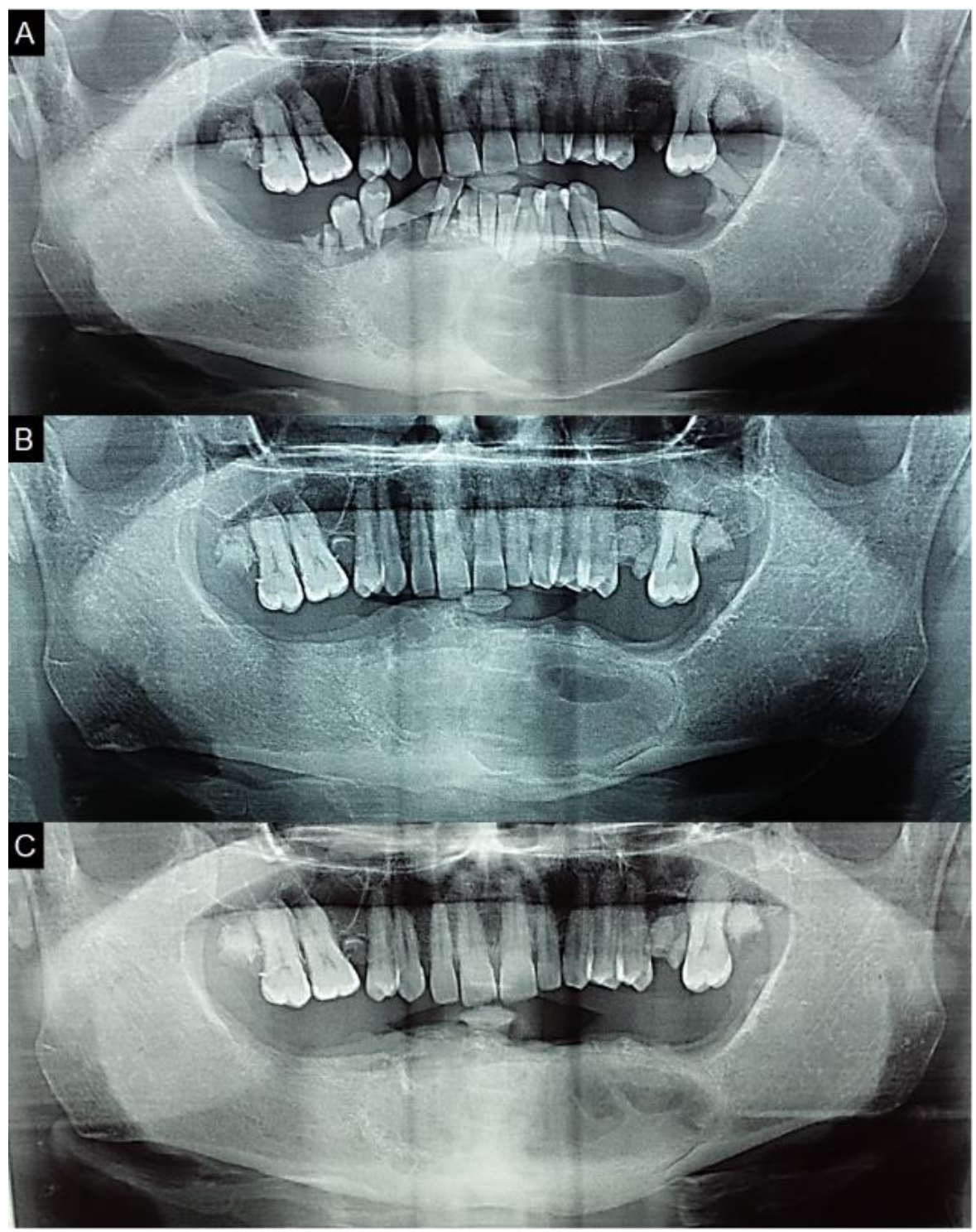

Figure 3. Panoramic radiograph. A, B and C: Panoramic radiographs showing new bone formation in the region. 


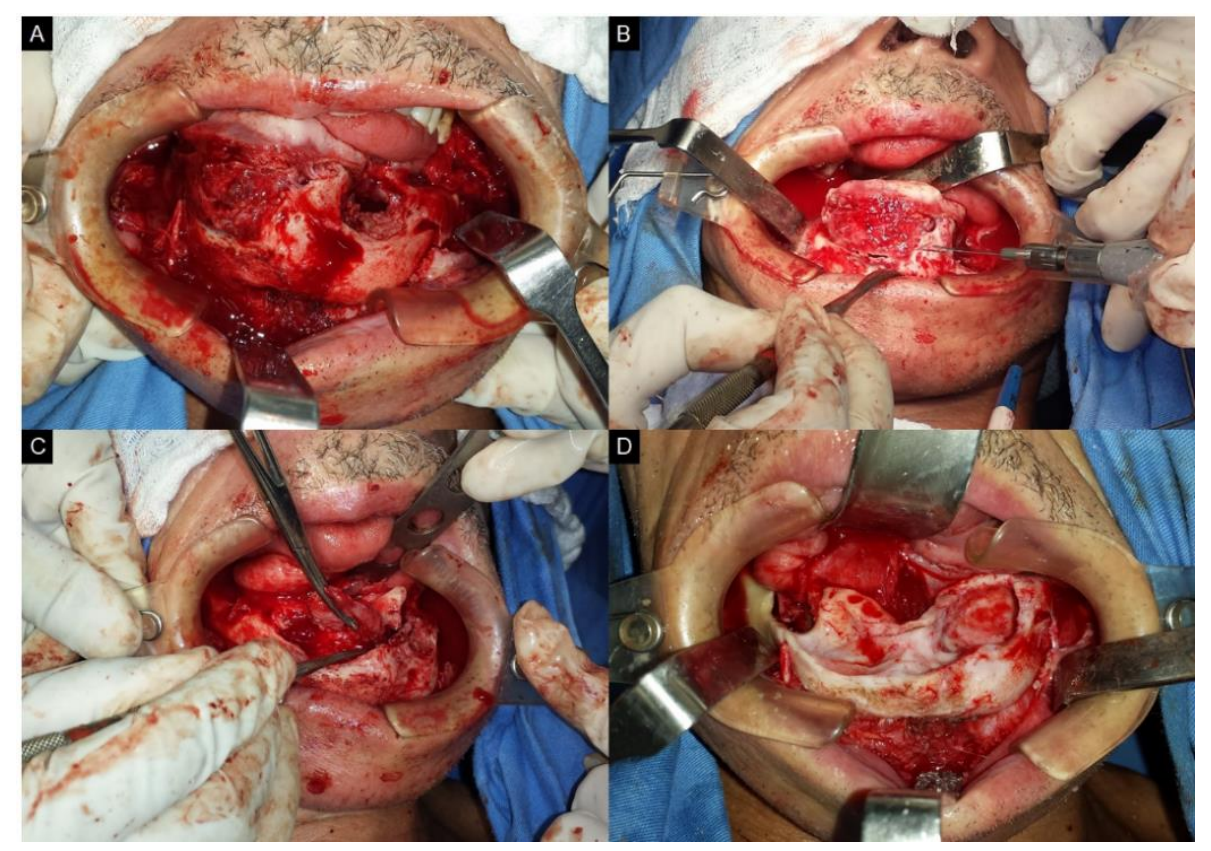

Figure. 4 Surgical approach to the lesion. A - Exposure of the tumor. B Peripheral ostetomy. C - Removal of the tumor. D - Bone defect after peripheral ostectomy.

After excision of the lesion (Figure 5), the material was sent for histopathological analysis, whose findings were of unicystic ameloblastoma, of the luminal type (Figure 6). The postoperative period occurred without any complications, after one month the patient did not present any facial alteration or infection (Figure 7) and is being monitored without signs of recurrence.

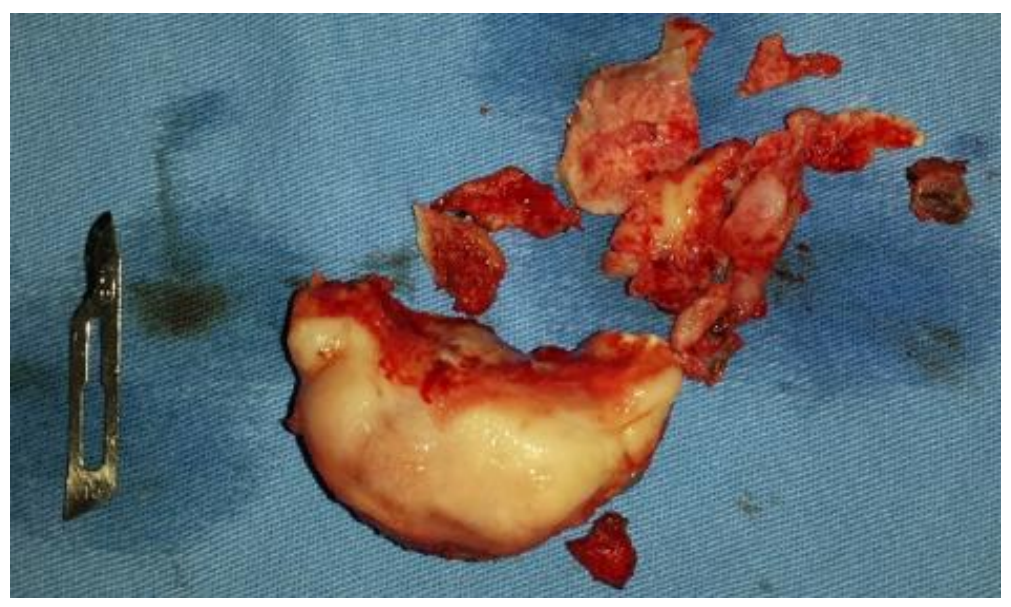

Figure 5. Surgical specimen. 


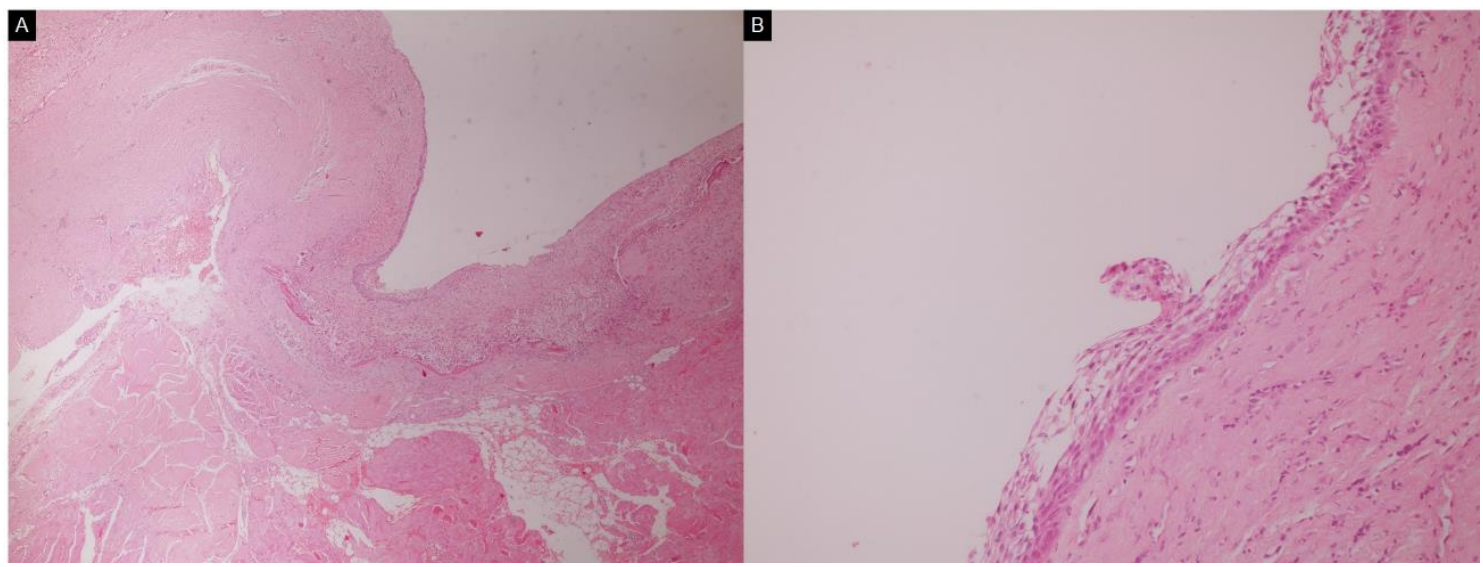

Figure 6. Histological analysis of the surgical specimen. A - Proximity of the tumor to the areas of fatty and striated skeletal muscle (hematoxylin-eosin stain, $\mathrm{x} 40$ ). B - The basal layer, presents cuboidal and columnar cells, of hyperchromatic nuclei, some of which have inverted polarization and arranged with palisades, the other layers are loosely arranged

(hematoxylin-eosin stain, $x$ 400).

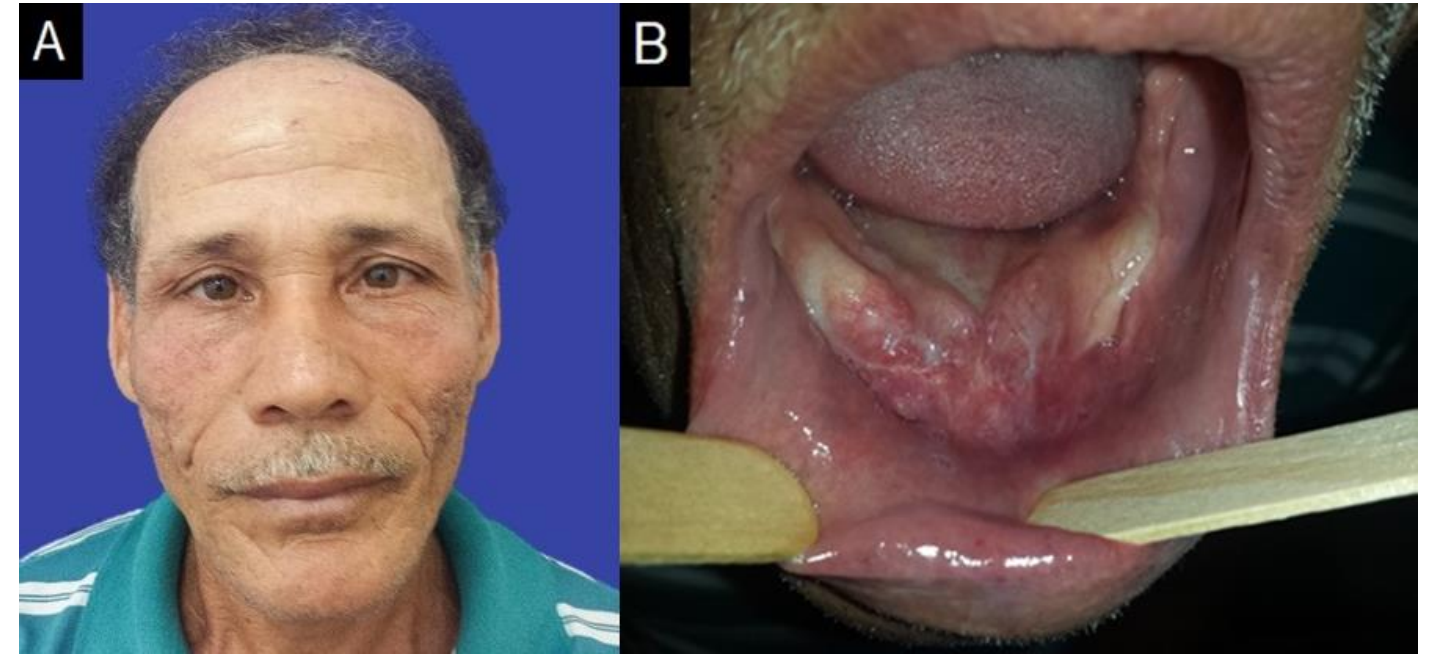

Figure 7. clinical evolution after 1 month. A: front view. B: intraoral view.

\section{Discussion}

Ameloblastoma is an uncommon benign odontogenic tumor, locally aggressive, which rarely causes metastasis, can reach considerable dimensions, causing facial deformity and functional impairment and if not treated properly it can reapper ${ }^{(14,15)}$. Unicystic ameloblastoma (UA), 
which is a clinical variant of ameloblastoma, is a cystic lesion, which presents clinical and radiographic characteristics of a cyst and histopathologically is formed by ameloblastomatous epithelium (16,17). This injury was first described by Robinson and Martinez in $197{ }^{(18,19)}$. The UA preferentially affects young patients, during the second decade of life, with an average age of 16 years and with a slight predilection for males. The lesion is usually asymptomatic, occurs in the posterior region of the mandible and is characterized by a painless swelling ${ }^{(6,20)}$. The patient in question had characteristics that fled slightly from the pattern found in the world literature, due to the age and location of the tumor.

Radiographically is usually a well-defined unilocular radiolucent lesion ${ }^{(4,14,20)}$, although less frequent, the multilocular aspect has been reported ${ }^{(5,17)}$. UA is classified histologically into groups, luminal, intraluminal and mural. In the luminal variant, the tumor is confined to the cystic lining. In the intraluminal variant, neoplastic epithelium is projected towards the cystic cavity. In the mural type, the capsule is infiltrated by the neoplastic epithelium. AU is usually less aggressive than solid, probably this behavior is associated with histological characteristics ${ }^{(18,19)}$. The studied patient presented a multilocular radiographic lesion, which, although less prevalent, has been reported.

The definitive treatment of ameloblastoma is surgical and it is usually a safe resection, with the possibility of removing soft tissue. However, the extent of surgical intervention and the adoption of conservative or radical measures remains controversial ${ }^{(4)}$. The management of ameloblastoma represents a challenge for surgeons, because it requires not only adequate resection, but also functional and aesthetic reconstruction of the residual defect ${ }^{(21)}$. Surgical treatment can be separated into conservative and radical methods, depending on histological, radiographic and clinical characteristics, such as location, size of the lesion and age of the patient ${ }^{(22,23)}$.

Radical treatment is characterized by mandibulectomy or segmental resection of the lesion with safety margins ${ }^{(4,5)}$. This form of treatment is associated with low recurrence of the lesion, however it can cause numerous complications, such as facial deformities, dysfunctions, and psychological changes ${ }^{(4,22)}$. Conservative $A U$ treatment consists of enucleation and/or marsupialization, combined or not with supportive techniques, such as curettage, peripheral ostectomy and cauterization. This technique is associated with less functional and aesthetic impairment, however, it may have a higher recurrence rate ${ }^{(4,5)}$. 
Decompression has long been used as a treatment for odontogenic cystic lesions, mainly in large extensions in the mandible. This technique promotes bone neoformation and prevents extensive surgery ${ }^{(2)}$. It is applied more frequently for unicystic ameloblastoma, although some surgeons also use it as a success for multicystic ameloblastoma ${ }^{(1,2,24)}$.

Peripheral ostectomy/curettage aims to remove the infiltrative tumor islands that may exist in the residual bone walls after simple enucleation. In order to destroy remnants of tumor islands, chemical cauterization can also be performed, through carnoy's solution, or physical, using liquid nitrogen ${ }^{(25)}$.

Conservative treatment represents a reliable approach to the management of unicystic ameloblastoma, presenting good aesthetic, functional and with low-risk of recurrence results $(2,4,10,23,24)$. In the patient described, the conservative technique was chosen, due to the initial size of the lesion and the clinical type of the tumor. Even if marginal resection was performed, it only happened after decompression and a significant reduction of the neoplasia. Carnoy's solution was not used, due to the risk of injury to the lower alveolar nerve and neither liquid nitrogen, due to the thickness of the bone remnant and the possibility of fracture, thus opting for peripheral ostectomy.

\section{Conclusion}

The reported case emphasizes the importance of more conservative treatment, especially for large-volume unicystic ameloblastoma. This approach has been described and associated with positive aesthetic and functional results, in addition to a lower recurrence rate, being positive when considering the impact of a more radical treatment on the patient.

\section{Conflict of interest}

The authors declare that they have no conflict of interest.

\section{References}

1. Effiom OA, Ogundana OM, Akinshipo AO, Akintoye SO. Ameloblastoma: current etiopathological concepts and management. Oral Dis. 2018; 24:307-316.

2. Yang Z, Liang $Q$, Yang L, Zheng GS, Zhang SE, Lao XM, et al. Marsupialization of mandibular cystic ameloblastoma: Retrospective study of 7 years. Head Neck. 2018;40(10):2172-2180. 
3. Ariji Y, Morita M, Katsumata A, Sugita Y, Naitoh M, Goto M, Izumi M, Kise Y, Shimozato K, Kurita K, Maeda H, Ariji E. Imaging features contributing to the diagnosis of ameloblastomas and keratocystic odontogenic tumours: logistic regression analysis. Dentomaxillofacial Radiology. 2011;40(3):133-140.

4. Nowair IM, Eid MK. A modified surgical approach for the treatment of mandibular unicystic ameloblastoma in young patients. J Craniomaxillofac Surg. 2020;48(2): 148-155.

5. Lopes SLC, Flores IL, Gamba TO, Santos RIF, Moraes MEL, Cabello AA, et al. Aggressive unicystic ameloblastoma affecting the posterior mandible: late diagnosis during orthodontic treatment. J Korean Assoc Oral Maxillofac Surg. 2017; 43(2):115-119.

6. Gundlach, K. Odontogene Tumoren. MKG-Chirurg. 2008;1:221-236.

7. Mendenhall WM, Werning JW, Fernandes R, Malyapa RS, Mendenhall NP. Ameloblastoma. American Journal of Clinical Oncology. 2007;30(6):645-648.

8. Chukwuneke FN, Anyanechi CE. Akpeh JO, Chukwuka A, Ekwueme OC. Clinical characteristics and presentation of ameloblastomas: an 8-year retrospective study of 240 cases in Eastern Nigeria. British Journal of Oral and Maxillofacial Surgery. 2016;54(4):384-387.

9. Bassey GO, Osunde OD, Anyanechi CE. Maxillofacial tumors and tumor-lik lesions in a nigerian teaching hospital: an eleven-year retrospective analysis. Afr Health Sci. 2014;14(1):56-63.

10. Zheng CY, Cao R, Hong WS, Sheng MC, Hu YJ. Marsupialisation for the treatment of unicystic ameloblastoma of the mandible: a long-term follow up of 116 cases. Br J Oral Maxillofac Surg 2019;57(7):655-662.

11. Masthan K, Anitha N, Krupaa J, Manikkam S. Ameloblastoma. J Pharm Bioall Sci. 2015;7, Suppl S1:167-70

12. Milman T, Ying G, Pan W et al. Ameloblastoma: 25 Year Experience at a Single Institution. Head and Neck Pathol. 2016;10:513-520.

13. Sham E, Leong J, Maher R, Schenberg M, Leung M, Mansourt AK. Mandibular Ameloblastoma: Clinical Experience and Literature Review. Anz. J. Surg. 2009 out;79(10): 739-744. 
14. Isolan CP, Moreira AG, Edges A, Post LK, Saavedra JPA. Successful conservative treatment of a mandibular unicystic ameloblastoma: 13-year follow-up. J Clin Exp Dent 2018 Nov; 10(11): e1123-e1126.

15. Rikhotso RE, Premviyasa V. Conservative Treatment of Ameloblastoma in a Pediatric Patient: A Case Report. J Oral Maxillofac Surg 2019;77(8):1643-1649.

16. Qahtani KAL, Alkhudhayri AF, Islam T, Mufargi KAL, Shakweer WAL, Otaibi F. Recurrent unicystic maxillary ameloblastoma presenting as unilateral proptosis. Saudi J Ophthalmol 2019;33(1):94-98.

17. Ghattamaneni S, Nallamala S, Guttikonda VR. Unicystic ameloblastoma in conjunction with peripheral ameloblastoma: A unique case report presenting with diverse histological patterns. J Oral Maxillofac Pathol. 2017;21(2):267-272.

18. Robinson L, Martinez MG. Unicystic ameloblastoma: a prognostically distinct entity. Cancer 1977;40(5):2278-85.

19. Sargolzaei S, Atarbashi-Moghadam S, Roohi A. Mandibular Mural Ameloblastoma with Unusual Histopathologic Features: a Rare Challenging Case. J Dent (Shiraz). 2019;20(4):304-307.

20. Wakoh M, Matsuzaka K, Imoto K, Goto T, Kamio T, Shibahara T. Luminal, Intramural Unicystic Ameloblastoma with Marked Fluid-Fluid Level: Validity of CT and MRI Findings. Bull Tokyo Dent Coll. 2020 12;61(1):61-69.

21. Adeel M, Raiput MAS, Arain AA, Abloch, M, Khan M. Ameloblastoma: Management and outcome. Cureus. 2018; 10(10):1-8.

22. Kim SW, Jee YJ, Lee DW, Kim HK. Conservative surgical treatment for ameloblastoma: a report of three cases. J Korean Assoc Oral Maxillofac Surg. 2018 Oct;44(5):242-247.

23. Hendra FN, Natsir Kalla DS, Van Cann EM, de Vet HCW, Helder MN, Forouzanfar T. Radical vs conservative treatment of intraosseous ameloblastoma: Systematic review and meta-analysis. Oral Dis. 2019;25(7):1683-1696.

24. Hasegawa T, Imai Y, Takeda D, Yasuoka D, Ri S, Shigeta T, et al. Retrospective study of ameloblastoma: the possibility of conservative treatment. Kobe J Med Sci. 2013 Nov 9;59(4):E112-21 
25. Shi S, Liu Y, Shan Y, Fu T, Zhao S. Enucleation combined with peripheral ostectomy: Its role in the management of large cystic ameloblastomas of the mandible. Journal of Cranio-Maxillofacial Surgery. 2014;42(8):1659-1663. 